\title{
Psychosocial Impacts of War and Trauma in Temsula Ao's Laburnum for My Head
}

\author{
Raam Kumar T. ${ }^{1} \&$ B. Padmanabhan ${ }^{2}$ \\ ${ }^{1}$ PhD Research Scholar, Department of English and Foreign Languages, Bharathiar \\ University, E-mail: raamkumar.efl@buc.edu.in \\ https://orcid.org/oooo-0003-0694-8671 \\ ${ }^{2}$ Assistant Professor, Department of English and Foreign Languages, Bharathiar University, \\ E-mail: padmanabhan@buc.edu.in \\ https://orcid.org/oooo-ooo1-7395-126X
}

\begin{abstract}
Violence constantly carries trauma and suffering to combatants as well as non- combatants identically. It also brings enmity and negativity to everyone both emotionally and physically. The cause for any conflict does not emerge from single motive but depends on multiple factors like socioeconomic conditions, marginalisation, discrimination, political power and sometimes even environmental elements. In recent times, the conflicts often emerge among various regional groups rather than states. North Eastern part of India is one of the hotspots for such ethnic conflicts and violence. The major motives for bloody conflict between Indian Army and the underground armed rebels are perceived political imbalance and desire for a separate nation. Even the common civilians are forced to join the rebel groups without knowing consequences. Temsula Ao is one of the prominent English writers from Nagaland who through her moving narratives brings out the existent misery of conflict in her native land. The aim of this paper is to study the psychological impact of domestic violence over the combatants as well as non-combatants whose lives are inseparably intertwined with violence and bloodshed. Though violence is considered as typical condition of human nature most of the time it leads to unbearable trauma and misery. This paper also attempts to interpret the representation of women from the marginalised Ao community who finds difficult to preserve the customs and moral values in spite of regional revolt.
\end{abstract}

Keywords: Psychological imbalance, Domestic violence, Aggression, North East India

North Eastern states of India continue to manifest their rich cultural traditions, folklores, myths and a unique way of life intertwined with nature. Though the states in the region are blessed abundantly with cultural values and natural resources they also witness violence, turmoil and conflicts in the name of race, ethnicity and national identity which lead to unprecedented misery of the general public. Poimila Raman (2018), in his article states that, "Violence and political unrest in the North-Eastern states of India go hand in hand in disrupting the ordinary lives of the people" (p. 140). Prolonged ethnic and political struggles in the region inflicted unimaginable damage to the lives of ordinary people and the prevalence of the chaotic atmosphere shattered the dreams of peaceful coexistence among various ethnic groups. The geographical location, lack of a common shared belief system, poor education and lack of sufficient political representation remain to be causes of the continuous conflicts and bloodshed in this region. Diehl (1991, as cited in Hensel, 2000) says that "conflict occurs specifically because of geographic factors and

(C) AesthetixMS 2020. This Open Access article is published under a Creative Commons Attribution Non-Commercial 4.o International License (http://creativecommons.org/licenses/by-nc/4.o/), which permits non-commercial re-use, distribution, and reproduction in any medium, provided the original work is properly cited. For citation use the DOI. For commercial re-use, please contact editor@rupkatha.com. 
geography as a 'facilitating condition for conflict"' (p. 1). Likewise in the views of Temsula Ao (2015), "The North- eastern identity is a misnomer ... no one should use this term because it defaces the real identity of the people living here. At best it has only a geographical and geopolitical relevance" she stated this in one of the interviews with Joshy Joseph. Temsula Ao is considered to be one of the eminent woman writers from the Naga community known for her sharp commentary of life in the Naga dominated regions. Most of her works bring out the pain and sufferings of the common people in a land mired by political and ethnic violence. She was honored with Padma Shri and Sahitya Akademi awards by the government of India for her contribution towards literature that honestly captures the social reality of Nagaland. This article discusses the psychological sufferings of combatants and non - combatants who invariably undergo the cruel, traumatic experiences of an armed struggle as portrayed in the work The Laburnum for My Head. The work also presents Ao's observations about the struggles of women to cope up with the necessities of life in a continuously evolving modern society.

Author begins the book with the lines, "Stories live in every heart; some get told, many others remain unheard ... sometimes prayers; and those that are not always a figment of the mind but are, at times, confessions" (Ao, 2009) manifesting author's intentions to express the inner turmoil of the people in the conflict zone. The uniqueness of the stories of Ao's is that they carry multiple human emotions within and deal with complex issues like nationalism, identity and trauma. Ao presents a very sensible and authentic representation of the region as her stories emerge from her first hand experiences in the region. Among the eight short stories in the collection the stories like 'The Letter', 'A Simple Question' and 'Sonny' deal with the horrors of violence resulting from the long battle between the underground rebels and the Indian armed forces. Through the portrayal of fictional characters Ao actually picturises the psychological turmoil and social problems experienced by both kind of people, those who take part in the armed struggle and those who stay away from it. Chatterjee (2010, as cited in Siambiakmawi, 2015) states that "Northeast has long been on the fringe of mainstream literary consciousness, edged out by its complex socio-politics, crisis if identity and the prolonged rule of the gun" (p. 26o). The other stories in the collection talk about the ethnic factors of the Naga society and the struggles of women adapting to modern conditions.

Psychosocial is the term commonly used to denote strong connection between the social and psychological factors influencing human life. Maryanne Loughry \& Carola Eyber (2003), as quoted from the Oxford English Dictionary defines psychosocial term as, "the influence of social factor on an individual's mind or behaviour, and to the interrelation of behavioural and social factors; also, more widely, pertaining to the interrelation of mind and society in human development" (p. 2). This gives the lucid idea that the term psychosocial implicates the inclusion of social issue over the thoughts and behaviour of human actions and vice versa. It can be easily understood from this perspective that violence plays a vital role in creating psychosocial problems in the regions like Nagaland where insurgency and armed struggle have become an inseparable part of their livelihood. "It would be a great lie, if a Naga failed to speak about the immense atrocities meted on a daily basis" (Daikho Manehrii, 2018, p. 81).

In the story 'The Letter' the author connects violence, militancy and poverty together and portrays that they remain to be inseparable in the miserable life of the people of this region. The atrocities of the so - called "national workers" (p. 55), the indifference of the government machinery and the helplessness of innocent people are truthfully captured. The story begins with the lines, "There was an uneasy quite in the village: the underground extortionists had come and gone and along with them the hard-earned cash the villagers had earned by digging the first 
alignment for a motorable road to their village" (Ao, p. 54). The villagers were assigned to construct a road for their own village by the Border Roads Organization. Due to lack of man power native villagers volunteered themselves for this project and they were paid for their work. Every individual had different plans for spending their money that includes buying bulls, reconstructing the roof of their home and so on. But they merely failed to reckon that they need to pay the share to the underground rebels. Once the salary is credited, the news reached the underground rebels and during the same night few strangers enter their village with weapons demanding money in the name of tax. Once the villagers sensed their presence they knew that their plans of spending money for their basic needs are shattered. The villagers are very much aware of their presence as, "these fierce-looking goons from the forest had come to the village at night with only one purpose: to rob them in the name of the underground government" (p. 55). They never tried to resist them because they believed it was of no use since the rebels carry weapons and any form of conflict would end in a catastrophe to their whole village. So with no other options they paid their 'tax' to the underground armed forces. Once the names were read out along with the amount to be paid, they started counting "with hatred in their hearts and murder in their eyes" (p. 55). One person appealed to the headman and said he could not pay the tax because he is in need to send the hard earned money to his son in order to pay his final examination fees within a week. On hearing this,

one of the extortionists shot out from the stool he was sitting on and hit the poor man with the butt of his rifle, 'What examination, what fees? Don't you know what sacrifices we have made in our fight against the government? And how we are suffering in the forest? Are you saying that we should not collect taxes so that your son can give examinations and become big "babus" in the Indian government to rule over us?' (Ao, p. 56)

The village headman intervene the conversation and saves the life of the poor villager who resisted paying money to the rebels. This story portrays the evils of meaningless war and the frustration created by the underground rebels in the name of national liberation. With regard to this the narrator includes another incident, where a few days later an unnamed underground militant visits the village asking the way to headman's house. An experienced woman recognizes him by his appearance. She is the woman in the village who had "seen the tortured victims, the so-called 'sympathizers' of the underground forces, and lived through the trauma in the wake of her husband's abduction and eventual killing by the underground (pp. 58-59). Her husband was killed because he worked as an informer for the Indian army. Like her many women have undergone traumatic experiences both mentally and physically by losing their family members. Knowing the motto of the new comer she directed him towards the members of a young group. With proper execution of plan they put him to death and the leader of the group found a letter from his pocket stating that, the dead man's son begging his father to send him money to pay his exam fees. The narrator has left this character and the situation to the judgement of the readers. The story indirectly points at a despicable scenario experienced by the people of the region as they find it difficult to distinguish personal problems with national issues.

The story also reveals that, most of the young people join rebel groups without knowing about the real motives of them. The underground government misleads the younger generation by projecting themselves as the real 'freedom fighters' who fight for the welfare of their state. Because of this many youth suffer and lose their lives. One such incident is depicted in the story titled 'Three Women' where the little sons join the rebel army. Lipoktula the mother of these sons insists that "we could not meet with the deadlines for paying fees, and the older boys sometimes 
could not sit for exams. In disgust both of them ran away and joined the Assam Rifles, after studying only up to class VI" (p. 72). It is not the nationalist ideology that motivates them but poverty since they have no other way to overcome it.

With the above instances it is evident that one of the socioeconomic factors like 'poverty' and administrative failure has played the key role in creating anger and discomfort among the mariginalised communities. The villagers were under stressful situations unable to handle life with poor income. These kind of poor living conditions often direct the youth to join the rebel groups.

Another story titled 'A Simple Question' discusses about the implications of political power over the villagers by both the underground rebels and the Indian government forces. The story embarks with an uneasy dream of Imdongla, a worldly-wise woman who had good knowledge about the politics and past history of her village. Most of the time her presence of mind had saved her husband Tekaba from hard times. Tekaba being the gaonburah is always targeted by the armed groups. They used to enjoy the power and prominent position at one side, but they also "become more vulnerable ones when hostilities broke out between the Nagas and the Indian state" (p. 81). They become clowns in the hands of underground groups and the government officials. If they fail to fulfill their demands they threatened them to destroy their village granaries by fire. In the beginning one rupee was demanded as the 'tax' amount by the underground rebels from each houses as,

the travel expenses of the rebel leader going to foreign lands to plead for Naga independence from India .... But as years went by the demands grew, and reluctance or protest was met with by severe beatings, not only of the person involved but of the gaonburahs and the elders as well. (Ao, p. 82)

Similarly those who fail to support the government were also punished by the authorities. The un-cooperative villagers were allotted to set army camps, and forced to clear the sideways of highways so that it will be easy for them to have a look at underground rebels. Those who refuse to accept to this deal "would be forced out of their villages; their houses and granaries would be burnt and they would be relocated along with other recalcitrant villagers ... not allowed to cultivate their fields" (p. 84). Here the impact social exclusion is highly evident where the owners of the lands were sent out of their village. Due to lack of political power a conflict emerges. Once Tekaba along with elders of his village was dragged to army camp for providing supplies to the jungle men, Imdongla diplomatically handled the situation. She reached the camp and protested to release her husband. When the captain of the army camp approached her, she is about to take off her clothes which could be the utmost insult of any Naga woman. By seeing it he quit the place and went out. While captain was mulling over other things Imdongla stated, "Fear of you Indian soldiers and fear of the mongrels of the jungle" (p. 87). Here the impact of power conflict is experienced by the people of Mokokchung village. They cannot even reap benefits from their native land. Even though they work in their fields and earn from it they find it difficult to enjoy it because they were forced to give it to the underground army. "we cannot live without rice. Don't you see what's happening to our children and women? (p. 85). It shows the real sufferings of the villagers where they were suppressed and meant to obey the orders of armed groups.

However, the next short story titled 'Sonny' conveys the traumatic experience of the dream-chaser Sonny who was gunned down by his fellow underground power brokers. Once Sonny said to his girlfriend, 
Sweetheart, you don't understand, this is something bigger that you or me and everything else put together. This is my destiny. (pp. 88-89).

Sonny was the person who bought good things in the life of his girlfriend but after his decision to join the underground group; their lives never remain to be the same. After joining the rebel group Sonny reached the highest rank and his admirers compared him to the enigmatic 'Che'. Though he attained his dream he was not satisfied with his life. This was revealed through a letter sent to his girlfriend. It contained the message,

Sweetheart, there were often times when I felt grateful that you did not try to stop me for going in, but now I wish you had. (p. 94).

Once the strong Sonny now became a man of despair is evident from the above mentioned words. Similar to his personal life, the people of the region have undergone stimulus anxiety where "Families were separated, women were raped and killed, and the men were forced to see humiliation before they too, were either maimed for life or simply killed" (p. 97). All these actions by the armed groups made the people to stay in fear and this created "a new sense of terror in the minds of the general public" (p. 88). Correspondingly, the ignorance of the poor innocent villagers is well narrated with an incident in the story 'The Boy Who Sold an Airfield'. The setting of the story was after the end of the Great War II and the villagers didn't know that the big war came to an end and whenever they hear the sounds of aircraft they felt that a huge disaster coming towards them.

They did not know that the Great War was over. They were so jittery that whenever they heard the planes they all ran into the nearby jungles (p. 48).

Their ignorance about the social and political happenings clearly depicts that the marginalised are kept away from the society. Their life seemed to be at chaos and complicated because of the violence and sufferings prevailing around them. The incidents and the characters of the above mentioned stories exhibit that the people have experienced the cruelty of violence and have undergone trauma. Jensen \& Shaw (1993, as cited in Amrita Rathi, n.d) views trauma as,

emotional sufferings related to war may occur not only due to direct exposure to lifethreatening situations and violence but also through indirect stressors, such as injury to or death of relatives or caregivers, economic hardships, geographical displacement, and continuous disruptions of daily livings. (n.p)

In other stories like 'Laburnum for My Head' and 'Three Women' women were given prominent roles. The author projects the tribal women who attempt to adapt to the ways of modern society find it difficult to compromise their traditions customs. In the story 'Laburnum for my Head' the protagonist Letina breaks the Naga patriarchal customs and takes decision on her own by making her presence in the cremation ground. "Lentina surprised everyone, including herself, by announcing that she was going to accompany her husband on his last journey" (p. 4). Apart from this, when she shared her plan of buying a plot to bury her after her death her driver was shocked and uttered, "But madam, your place is already earmarked beside my master!" (p. 6). She is very much disappointed by this response. She is conscious on her plan that her tombstone should be covered with the blossoms of yellow laburnum flower. "I need a place where there will be nothing but beautiful trees over my grave" (p.9). The ambitious woman who is ready to banish the traditions of her village is portrayed in the story. On the other side, the story 'Three Women' discusses the three generations of women who faced misery at different stages of their life. Lipoktula the first generation woman and the grandmother has been sexually assaulted by the landlord of her village. Her daughter Medemla belongs to second generation and she has been 
deserted by her lover. Martha the adopted child of Medemla who actually belongs to 'tea tribe' also experiences the racial discrimination. Whenever she went out for playing the children tease her with the name 'coolie' and make fun of her dark complexion. Even when she joined in a school, "They did not want to sit near me or play with me" (p. 64). Martha's father, who lost his wife, left the new born child alone in the hospital murmuring that "What will I do with another girl? Do whatever you want; I don't want to see her ever (p. 68). Here the author brings out the complexities in the lives of women during different periods of time. The sufferings of women remain to be the same with different factors according to prevailing social conditions.

Temsula's Laburnum for My Head captures the pictures of irony, traumatic experiences, aggression and conflict with deep analysis of human conditions at different levels of the society. The conflicts between underground rebels and the Indian Forces in Nagaland can be considered as the domestic conflict as it is limited to a particular region and involves few ethnic groups claiming territorial sovereignty.

According to John Doyle \& Priyanka Talwar (2013),

India's domestic conflict might be categorized under three themes, based on the issues raised or demands made during the conflict that is - territorial disputes, developmental conflicts and localized communal conflicts.

The struggles in the North Eastern states of India are largely based on the claims of ethnic superiority, cultural imposition and caused by lack of development. The Northeast region is secluded geographically from the mainland of India because of poor infrastructure and lack of transportation as the governments lack vision to establish dependable infrastructure in the hostile mountainous terrains. This makes it as one of the underdeveloped regions of India (Nongzaimayum et al., 2018). The stories also picturise a perspective that the problems exist in this region are not irresolvable. (Cohen, 2011), suggests that, if the local communities are provided with adequate representation in political system it will reduce the number of people resorting to violent means. Though violence is a common factor and affects the society it can be kept under control by addressing the genuine concerns of the communities. In the words of James Gilligan (1997), as analysed by Jennifer Lawson \& Bryn King (2012) "violence as a public health problem that is preventable when there is a will to examine and address the root cause of violent behavior" (p. 518). The problems that cause unrest and trouble in the north east are not properly addressed by the authorities, but they resort to high handedness in dealing with the concerns of the people. The failure of the administrative system in understanding the trauma undergone by these marginalised people strengthens the public belief that they are neglected and their genuine concerns are not addressed properly. Thus, Temsula's depiction of the despicable lives of the native people manifests that their lives are filled with misery and the effects of insurgency lead to problems not only for individuals but for their whole society. Temsula uses writing as a tool to bring harmony and peace. To say in her own verse, "I hear the land cry/ Over and over again/ Let all the dead awaken/ And teach the living/ How not to die" (Ao, 2006, vi).

\section{References}

Alee, N. T., Hasan, A., \& Aijaz, A. (2018). Mental health and psychological problems in north east India. IAHRW International Journal of Social Sciences, 6(5), 817820. https://www.researchgate.net/project/Mental-Health-and-psychological-problems-in-NorthEast-India 
7 | Psychosocial Impacts of War and Trauma in Temsula Ao's Laburnum for My Head

Ao, T. (2006). Lest We Forget. In These hills called home: Stories from a war zone. Zubaan.

Ao, T. (2009). Laburnum for my head: Stories. Penguin Books India.

Dahrendorf, R. (2006). Conflict and Critical Theories. Retrieved from http://www.sagepub.com/upmdata/13636_Chapter7.pdf

Doyle, J., \& Talwar, P. (2013, September). Domestic Conflicts in India: The Impact of Legitimisation Strategies on Negotiations [Paper presentation]. European Consortium for Political General Conference, Bordeaux. https://ecpr.eu/Filestore/PaperProposal/6fofgbdı-focc-4ad6-aae4eefgc296761c.pdf

Hensel, P. R. (2000). Territory: Theory and Evidence on Geography and Conflict. Semanticscholar. https://pdfs.semanticscholar.org/d318/o3b7664c75aoeic7b9d6ada2206bo392cbd4 .pdf

Joseph, J. (2015, October 24). The North-eastern identity is a misnomer. Interview by A. Temsula. The Statesman. https://www.thestatesman.com/supplements/the-north-eastern-identity-is-amisnomer-99086.html

Krishna, S. (2018). Voices of the Voiceless: A close Analysis of Temsula Ao's Soaba and The Last Song. International Journal of English Language, Literature in Humanities, 6(1), 520-525. https://ijellh.com/OJS/index.php/OJS/article/view/2893

Lawson, J., \& King, B. (2012). Theories of violence: A review of textbooks on human behavior and the social environment. Journal of Human Behavior in the Social Environment, 22(5), 517534. https://doi.org/10.1080/10911359.2011.598724

Loughry, M., Eyber, C., National Research Council (US) Committee on Population, \& Program on Forced Migration and Health at the Mailman School of Public Health, Columbia University. (2003). Psychosocial Concepts in Humanitarian Work with Children: A Review of the Concepts and Related Literature. National Academies Press (US). https://www.nap.edu/catalog/10698/psychosocial-concepts-in-humanitarian-work-with-childrena-review-of

Raman, P. (2018). A Study on the Select Literary Works of Temsula Ao, Easterin Kire and Monalisa Chankija as Resistance Literature. Literary Herald, $3(6)$, 140-

147. http://tlhjournal.com/uploads/products/20.poimila-raman-article.pdf

Rathi, Amrita. (n.d.). Psychological Impact of victims of War and Conflict. American Psychological Association (APA). https://www.apa.org/international/united-nations/un-matters/rathi-war.pdf

Siambiakmawi. (2015). Between ethnicity and Modernity: A study on Dr. Temsula Ao's Laburnum for my Head. International Journal of English Language, Literature and Translation Studies, 2(2), 259269. http://www.ijelr.in/2.2.15/259-269\%20SIAMBIAKMAWI.pdf

Raam Kumar T. is a PhD candidate in the Department of English and Foreign Languages, Bharathiar University, Coimbatore, Tamil Nadu. He is working as a Project Assistant for RUSA 2.0 - BEICH sponsored by MHRD. His current doctoral research is on Indigenous Literature in Indian Historiography focusing on the Eastern and Northeastern parts of India.

Dr. B. Padmanabhan is currently serving as Assistant professor in the Department of English and Foreign Languages, Bharathiar University from 2011, teaching postgraduate students and doing research in cognitive literary studies. His other research interests are ethnic and area studies, memory studies, post-colonial literature and Digital Humanities. 